\title{
A EUDAIMONIA, O BEM MAIS DIGNO DE SER ESCOLHIDO.
}

\author{
$\underline{\text { Isaias Azevedo Rocha }}{ }^{1}$; Adriana Santos Tabosa ${ }^{2}$. \\ 1. Isaias Azevedo Rocha PIBIC/CNPq, Graduando em Filosofia, Universidade Estadual de Feira de Santana, e-mail: \\ isaias_mill@hotmail.com \\ 2. Adriana Santos Tabosa, Departamento de Ciências Humanas e Filosofia, Universidade Estadual de Feira de \\ Santana, e-mail: adriana_tabosa@bol.com.br \\ 3. Participante do projeto Nomisma, riqueza e valor: um estudo sobre o pensamento econômico de Aristóteles, \\ Departamento de Ciências Humanas e Filosofia, Universidade Estadual de Feira de Santana, e-mail: \\ adriana_tabosa@bol.com.br
}

PALAVRAS-CHAVE: eudaimonia; energeia; ergon.

\section{INTRODUÇÃO}

Para a construção do arcabouço teórico deste trabalho, foram utilizados os estudos de Aristóteles como teórico principal, que versa sobre o seu pensamento ético bem como os estudos de outros teóricos comentadores do filósofo principal, como Zingano, Wolf, Kraut, Lawrence e Ross.

Segundo Aristóteles, toda investigação, toda ação e toda decisão visam algum bem, desse modo, pode-se afirmar que tudo aquilo a que o homem aspira é chamado de bem (agathon), ou seja, Aristóteles afirma que existe um "bem humano". Mas, o que seria esse bem humano? A respeito desse questionamento, Gavin Lawrence (2009, p. 43) diz que:

Não apenas podemos perguntar pelo que é o melhor a ser feito, mas o próprio ato de perguntar e buscar isso é o que significa ser racional no sentido pratico. O "bem humano", assim concebido, é simplesmente o objeto (formal) do propósito racional.

Assim, uma resposta superficial para esse questionamento é a de que o bem humano seria simplesmente uma vida boa e bem-sucedida, pois é isso que a maioria dos homens busca incansavelmente. Desse modo, parece que viver bem é a melhor coisa que se pode buscar na vida. Portanto, a tarefa da razão seria buscar essa vida agradável e um modo de preservá-la, ao que parece, viver bem é ter uma vida boa. Segundo Gavin Lawrence (2009), essa vida boa é mais do que a satisfação dos desejos que desejamos ter, tem outras questões que contam como ser bem-educado nos modos de proceder das virtudes - ter o critério correto de sucesso na ação e uma experiência geral de vida.

Para Aristóteles, existem dois tipos de atividades: as que não possuem um fim distinto da ação em si, uma energeia e existem atividades, cujo fim é distinto da própria ação, ergon, como assevera o autor ao enunciar que 
Mas entre os fins observa-se uma certa diversidade: alguns são atividades, outros são produtos distintos das atividades das quais resultam; e onde há fins distintos das ações, tais fins são, por natureza, mais excelentes do que as últimas. (Et. Nic. I, 1094a, 3-4).

Considerando essa distinção, Aristóteles estabelece uma ordem hierárquica para as atividades. São superiores as atividades que não possuem um fim distinto da ação em si, como por exemplo, o ato de ver, o ato de pensar e também o agir ético $^{1}$. São inferiores as atividades, cujo fim é distinto das ações, como todas as atividades que geram um produto: o ato de construir, o ato de fabricar. Nesse sentido, o fim da ação da construção de uma casa não é o ato em si de construir, mas o seu produto - a casa.

\section{MATERIAL E MÉTODOS OU METODOLOGIA (ou equivalente)}

A metodologia desta pesquisa está constituída em: pesquisa da referência bibliográfica pertinente à temática, leitura e analise sistemáticas dos textos, compreensão e identificação do discurso, da argumentação, da fundamentação teórica.

\section{RESULTADOS E/OU DISCUSSÃO (ou Análise e discussão dos resultados)}

Considerando essa argumentação, que Aristóteles apresenta, a vida contemplativa é um exercício de busca pelo saber filosófico, pois essa é a atividade mais agradável e continua de todas, proporcionando sabedoria e prazeres puros. Em continuidade com o que já foi dito, o filósofo tem a capacidade de exercer a atividade da contemplação mesmo quando está sozinho, quanto mais sábio ele for melhor desenvolverá sua atividade, apesar do mesmo ser o mais autossuficiente dos homens, ele poderá desenvolver sua atividade de forma mais perfeita se possuir companheiros de atividade. Ademais, essa seria a forma de vida elevada para o homem como se algo divino o habitasse, como sugere Aristóteles ao abordar que:

[...] esta atividade é superior às outras formas de excelência na mesma proporção em que este "algo divino" é superior a nossa natureza heterogenia. Então, se o intelecto é divino em comparação com as outras partes do homem, a vida conforme ao intelecto é divina em comparação com a vida puramente humana. Mas não devemos seguir aquelas pessoas que nos instam a, sendo humanos, pensar em

\footnotetext{
${ }^{1}$ Ursula Wolf diz que o agir ético deve ser evocado pelo conceito de proairesis (decidir-se, decisão, escolher), que é o decidir pelo exercício de uma propriedade de caráter, por exemplo a coragem.
} 
coisas humanas, e sendo mortais, a pensar no que é mortal, ao contrario, devemos tanto quanto possível agir como se fossemos imortais, e esforçarmo-nos para viver de acordo com o que há de melhor em nós [...] (Et. Nic. X 1178a, 203).

\section{CONSIDERAÇÕES FINAIS (ou Conclusão)}

A eudaimonia é o bem mais digno de ser escolhido, e não pode ser posto como um bem entre outros, pois, se fosse enumerado entre outros bens à soma de eudaimonia, mais outros bens menores seriam maiores que só a eudaimonia. Portanto, um fim é absolutamente final quando interrompe a aspiração do homem por outros fins e torna boa a sua vida.

\section{REFERENCIAS}

ARISTÓTELES. Ética a Nicômacos. Tradução de Mário da Gama Kury. Brasília: Editora Universidade de Brasília, 4ª ed., 2001.

LAWRENCE, Gavin. O Bem Humano e a Função Humana, In: KRAUT, Richard. Aristóteles: a Ética a Nicômaco. Tradução de Alfredo Storck. Porto Alegre: Artmed, 2009.

KRAUT, Richard. Aristóteles: a Ética a Nicômaco. Tradução de Alfredo Storck. Porto Alegre: Artmed, 2009.

ROSS, Sir David. Aristóteles. Lisboa. Ed, Dom Quixote, 1987.

WOLF, Ursula. A Ética a Nicômaco de Aristóteles. Tradução de Enio Paulo Giachini. 2a edição. São Paulo: Edições Loyola, 2013.

ZINGANO, Marco. Estudo de ética antiga. São Paulo. Discurso editorial, $2^{\text {a }}$ ed.,2009. 